\title{
The impact of Covid-19 on E-business practices and consumer buying behavior in a developing country
}

\section{El impacto de Covid-19 en las prácticas de comercio electrónico y el comportamiento de compra de los consumidores en un país en desarrollo}

Received: January 28, 2021

\author{
Accepted: March 5, 2021 \\ Written by: \\ Fakhr E Alam Afridi ${ }^{22}$ \\ https://orcid.org/0000-0001-9776-5074 \\ Shahid Jan ${ }^{23}$ \\ https://orcid.org/0000-0001-8518-7668 \\ Bushra Ayaz ${ }^{24}$ \\ https://orcid.org/0000-0002-8999-4165 \\ Muhammad Irfan ${ }^{25}$ \\ https://orcid.org/0000-0002-9821-3383
}

\begin{abstract}
Online trade has shown a sharp increase since the outbreak of pandemic Coronavirus. The COVID19 has affected almost all financial and business activities around the world, even in Pakistan. It has changed the way consumers used to shop before the pandemic outbreak. Many companies until recently have developed and created their online stores and making up the most of their sales using internet channel. Consumer have no other choice but shop from home. In this research study, we discuss the impact of COVID-19 on ebusiness practices and consumer behavior in Pakistan. The theory of acceptance model has been applied where consumer behavior, ebusiness, and COVID-19, and posted as a key construct of the proposed research model. Structural Equation Modelling approach has been used to examine the interrelationship of variables of research. We applied two-step recommended Structural Equation Modelling approach, first, validate the constructs by using Confirmatory Factor Analysis, and then conducted Structural Equation Modelling path analysis and report the results, which indicated that in the present scenario COVID-19 has significantly impacted both e-businesses and consumer buying behavior in the context of Pakistan. This research briefly highlights the ecommerce trends and discusses the rapidly
\end{abstract}

\section{Resumen}

El comercio en línea ha mostrado un fuerte aumento desde el brote de coronavirus pandémico. El COVID-19 ha afectado a casi todas las actividades financieras y comerciales del mundo, incluso en Pakistán. Ha cambiado la forma en que los consumidores solían comprar antes del brote pandémico. Muchas empresas hasta hace poco han desarrollado y creado sus tiendas online y han aprovechado al máximo sus ventas a través del canal de Internet. El consumidor no tiene otra opción que comprar desde casa. En este estudio de investigación, discutimos el impacto de COVID19 en las prácticas de comercio electrónico y el comportamiento del consumidor en Pakistán. La teoría del modelo de aceptación se ha aplicado en el comportamiento del consumidor, comercio electrónico y COVID-19, y se ha publicado como una construcción clave del modelo de investigación propuesto. El enfoque de Modelización de ecuaciones estructurales se ha utilizado para examinar la interrelación de las variables de investigación. Aplicamos el enfoque de modelado de ecuaciones estructurales recomendado en dos pasos, primero, validamos los constructos mediante el uso del análisis factorial confirmatorio, y luego realizamos un análisis de la ruta del modelado de ecuaciones estructurales e informamos los resultados, que indicaron que en el escenario actual COVID-19 ha impactado

\footnotetext{
${ }^{22} \mathrm{Ph}$.D. Scholar, Islamia College Peshawar, Pakistan.

${ }^{23}$ Associate Professor, Islamia College Peshawar, Pakistan.

${ }^{24}$ Ph.D. Scholar, Islamia College Peshawar, Pakistan.

${ }_{25}$ Ph.D. Scholar, Islamia College Peshawar, Pakistan.
} 
growing scope for online businesses and makes several future research suggestions, especially in the context of cultural and other barriers such as digital payment adoption in developing economies. This study limitation is the study sample and context-specific to Pakistan.

Key Words: E-business, COVID-19, Consumer behavior, Structure equation modeling. significativamente tanto -comportamiento de compra de empresas y consumidores en el contexto de Pakistán. Esta investigación destaca brevemente las tendencias del comercio electrónico y analiza el alcance de rápido crecimiento para los negocios en línea y hace varias sugerencias de investigación futura, especialmente en el contexto de barreras culturales y de otro tipo, como la adopción de pagos digitales en las economías en desarrollo. Esta limitación del estudio es la muestra del estudio y el contexto específico de Pakistán.

Palabras clave: comercio electrónico, COVID19, comportamiento del consumidor, modelado de ecuaciones de estructura.

Chin, Altaf, \& Bajwa, 2020). The effects of this pandemic are unstoppable (Cohen, 2020).

The pandemic, COVID-19 was unknown until the outbreak started in Wuhan city of China, in December 2019. It was declared as a Public Health Emergency of International Concern by World Health Organization on 30 January 2020 (Zhong, Zheng, Kang, Li, \& Yang, 2020). Since then the COVID-19 for those who least able to cope is a moving wave that may yet to crash. It is not only just a health crises for the countries it touches, but it has disturbed the social, political, religious, economic, and financial structure of the entire world (McKinsey \& Pappas, 2020). Many economists warn that Covid-19 will have a negative severe impact on the world economy (Baldwin \& Mauro, 2020; Gössling, Scott, \& Hall, 2020; Hall, Scott, \& Gössling, 2020).

The economic damage is largely driven by a fall in demand for goods and services (Kowalewski \& Śpiewanowski, 2020). This indicates that consumers for goods and services are available in a limited number or they have significantly reduced their consumptions (Gretzel et al., 2020). This dynamic can be seen and applies to various industries, such as travel and tourism (Dunford, Gao, \& Li, 2020; Neubauer, 2020), and due to restrictions on other social events on holidays, and there is falling demand for new cars and oil as well (Wagner, 2020). Online commerce is struggling to sell online due to facing issues while sourcing their business products (Bounie, Camara, \& Galbraith, 2020). In the South Asian region many sectors in which China deals such as, instruments, machinery, and equipments related to communication, and technologies will affect its neighboring countries' business (Myers, 2020). The outbreak of the pandemic virus has changed the buyers, purchasing habits all over the world within a month (Shahzad,
Pakistan has also adopted the protocols of lockdown in continuation to the directives of WHO for every country to follow the procedures of lockdown as a means of preventing the pandemic's spread. However, in the present situation analysis predict that it has messed up due to the coronavirus. An online survey conducted by SMEDA (April 2020) "Impact of Covid-19onSMEs", the result highlights, $95 \%$ of enterprises have experienced a reduction in operations, $92 \%$ reports disruption in supply chain, $23 \%$ reports to $100 \%$ loss in export orders, $48 \%$ enterprise have laid off employees, while $26 \%$ plan to rehire laid-off employees in a month, and $89 \%$ enterprises facing financial issues. However, it is unavoidable fact that the pandemic will have a significant effect on the economy and social system of the country. The increasing threat not only significantly contributes to the health crises, but also hampers the country's macroeconomy as a whole. The present situation is becoming worse for the manufacturer as well as producers and expected more to be hampered soon (Craven, Liu, Mysore, \& Wilson, 2020). In south Asia, China acts as a central manufacturing hub for various businesses Cook and Yogendran (2020) such as machinery, instruments, health, and communication-related equipment (UNCTAD, 2020). Therefore, any disruption in china's output will simply have repercussions (Meyer, 2020), and will affect other country businesses (Sharot \& Sunstein, 2020). However, Pakistan's e-commerce index shows growing demand for online shopping and an increase in digital payment. According to Federal IT Secretary 
Shoaib on $16^{\text {th }}$ April 2020, there is a shift towards online digital payment methods since 2019 . He further added, that Darazpk (one of the leading online shopping stores in Pakistan) contributed $32 \%$ of the total online consumer spending and increased the use of e-wallets by $8.2 \%$ yearly.

Pakistani business markets are very much dependable on the products of China and the trade with China has a significant impact on Pakistan's economy. The lockdown imposed during the pandemic has further obstructed the export and import facilities in the country. This may also result in increased product prices in near future (Craven et al., 2020). However, an important research challenge for marketers is to determine how consumers seek to avoid information and how those decisions affect their behavior (Venkatesh, Morris, Davis, \& Davis, 2003). Social media platforms have access to an unprecedented amount of content (Ahmed, Ahmad, Ahmad, \& Zakaria, 2019) and may amplify rumors and questionable information (Kulshrestha et al., 2017). Staying home and social distancing is expected further to push consumer towards online shopping.

As per a recent Gallup Pakistan survey, many people switched to mobile and internet banking due to precautionary measures against COVID19. In online banking, one can perform digital financial activities of money transfer transactions, to mobile top-up. During the first quarter of the present year, 14 million transactions of total value 748 billion rupees were processed through internet banking, a growth of 6 percent by banking. The online internet and mobile transactions are quite promising and expected that the upward trend will continue in near future due to the steps taken by the Government and SBP (State Bank of Pakistan), to promote digitalization in a painful time. However, the uncertainty issue in supply and demand can affect the e-commerce industry. Moreover, the uncertain situation and lockdown also obstructed the export and import channel in the country. Due to the shortage of the products, online business is unable to meet and satisfy the customer's demand, this may result in price spike for products in near future.

The adoption of e-commerce in Pakistan relatively novel phenomenon from both perspective consumers and producers. In developing countries, small and medium-sized enterprises are still unable to adopt e-commerce quickly. Unfortunately, there is no known study available especially in the context of Pakistan.
Therefore this study will act as a bridge to fill the gap in the available literature. Moreover, this study will also be unique for the country's literature as in past no single study such as have been conducted in any pandemic disasters.

\section{Literature Review}

It was established soon after reporting COVID-19, that human-to-human transmission taking place (N. Chen et al., 2020; Lai, Shih, Ko, Tang, \& Hsueh, 2020). Researchers all around the world documented their greater concerns about the dramatic impact of COVID-19 on the world economies. Like, Inoue and Todo (2020) observed how firms in Tokyo shutting down, resulted in output loss. Bullard (2020) examined the possible effect on the US economy and argued that half of the economy will suffer due to the rapid emergence of COVID-19 in the US. However, a surveybased study by Baldwin and Mauro (2020) in the last week of March estimated that 65 percent of the French economy is at its normal level. While Muellbauer (2020) examined COVID-19 impact on GDP in the loss. Likewise, Barrot, Grassi, and Sauvagnat (2020) pointed out the essential list of the affected industry due to virus, such as the closure of schools, and working from home. While McKibbin and Fernando (2020) argued that shortage of labor supply is because of morbidity due to infection. Similar results were reported by many previous researchers (Bartik et al., 2020; Cajner et al., 2020; Coibion et al., 2020).

Although the relationship between technology and commerce has long existed, however in recent decades, advancement and development in information communication technology have led to the evolution of global commerce, which is the process involved in many fields such as, economy, commerce, customs, banking, etc. (Rahayu \& Day, 2015). Jai, Burns, and King (2013) argued that traditional commerce no longer could respond to the needed component of consumer's lives. Further added by Apăvăloaie (2014), the internet has been greatly admired by people of all over the world and it plays an important and significant role in over life Hajli, (2014), this has resulted in revolutionary changes in commerce and business (W. Chen et al., 2003).

Information communication technology advancement has impacted economy and society (Fang, 2014; Hajli, 2014), considered to be the greatest innovative application related to economic and commercial processes (Abebe, 
2014), which led the creation to referred to as electronic commerce with an important assigned role in economic affairs globally (Feizollahi, Shirmohammadi, Kahreh, \& Kaherh, 2014).

Sebora, Lee, and Sukasame (2009) suggested that business firms can get benefit from the novel $\&$ modern methods of doing online business such as electronic commerce, and through their effective commercial process, it may play a key role in the success of the firms. Digital connectivity dramatically has changed people's lifestyles in many countries (MacGregor \& Vrazalic, 2005). However, According to Tarhini, Alalwan, Shammout, and Al-Badi (2019), although it provides opportunities for small businesses to compete in developing economies, e-commerce adoption in developing economies still faces barriers due to the relatively new phenomena. However, for economic purposes ecommerce is considered the best instance in which ICT (information communication technology) are applied to enhance commercial efficiency and support economic development and growth particularly in developing countries (Hollenbeck \& Kaikati, 2012). Business organizations have to welcome, adapt and apply new technologies to get benefit from competitive advantage and to stop using traditional commercial methods (Borges, Hoppen, \& Luce, 2009). However, trust is important, particularly in e-commerce transactions (Grabner-Kräuter \& Kaluscha, 2003). Jahng, Krug, and Zhang (2007) argued although the internet is a key facilitator in business and communication activities; however, it has still ways to attain true e-commerce potential. Some researchers believe that due to the lack of trust in the system which facilitates the exchange, slow speed to grow and its potential yet has to be realized (Dinev \& Hart, 2006).

\section{Consumer Buying Behavior Pattern and E-commerce}

\section{Trend and Practices of E-commerce in Pakistan.}

Though electronic commerce in Pakistan started in the year 2001, yet, the first online dedicated system was initiated in the year 2009 by the cellular company "Telenor" with mobile account service "Easypaisa" through which users can perform money transactions within the country. However, with the advancement of information technology, electronic commerce is exploring fast-growing new business areas like online trading of financial instruments e.g. public or private limited companies shares over the internet, this also includes purchase and sale of commodities currencies and many others. The World Wide Web makes possible almost all financial transactions can be performed by using computer devices through proprietary software. This enables consumer's ability to search and purchase a wide range of various industries' products and services. Before the outbreak of COVID-19, internet users' steady growth across the globe and rising awareness, is the strong factor behind the driven growth of online shopping. Besides, increasing numbers of products online launching, bulk purchase due to low price offer also contributed to boosting online consumer purchases. Moreover, this greater number of product availability, direct distribution channel due to improved transportation grid, and economies of scale play their role in increasing the global electronic market (Boore, James, \& Iraki, 2017). 


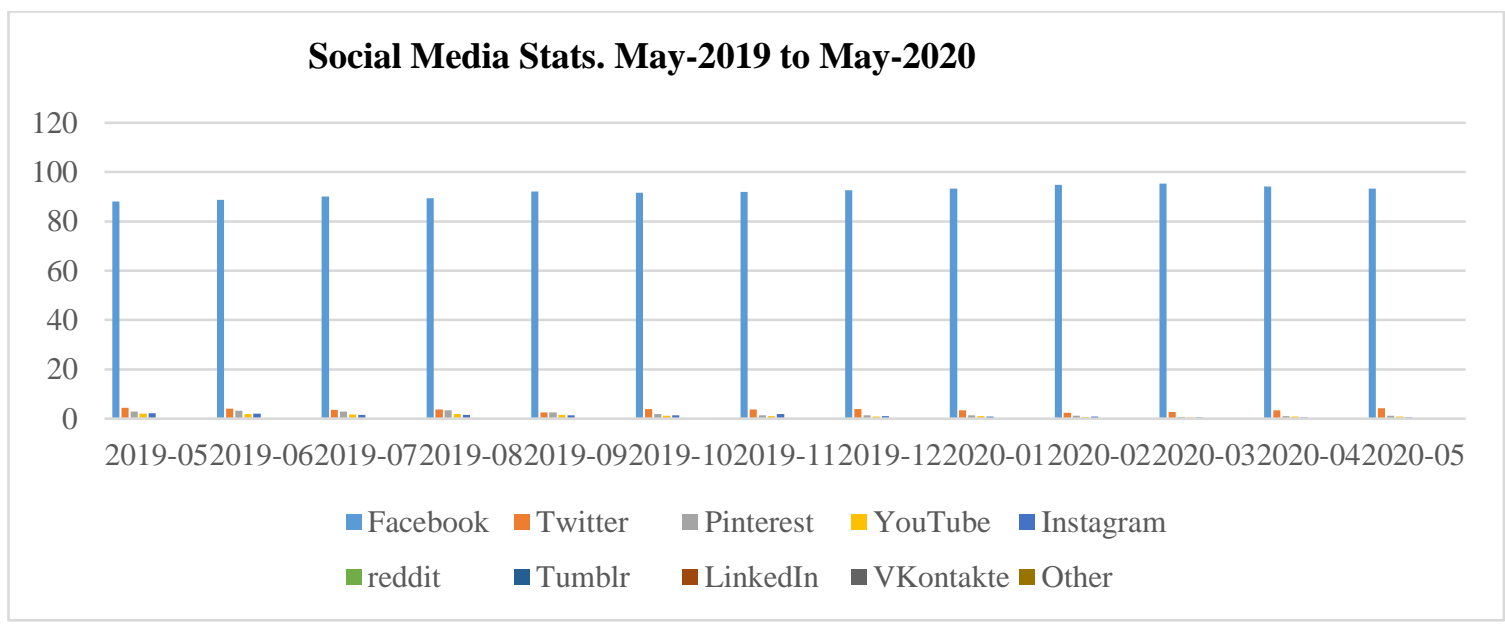

Graph 1. Social media users (source: www.gs.statcounter.com)

According to internet world stats, there are 44.61 million internet users at the penetration of $22.2 \%$ in Pakistan. However, due to a lack of infrastructure and other resources internet penetration is still very limited. Unstable economic circumstances, low literacy, and cultural resistance are on the top of the list that keeps the penetration low. However, due to the cheap availability of $3 \mathrm{G} / 4 \mathrm{G}$, and affordable mobile resulting in high internet penetration. In March 2017, according to The Express Tribune, there are more than 137 million mobile phone users in Pakistan. However, only 30 percent use the internet on their mobile phone in the year 2017. One of the few reasons mainly behind this is the lack of internet services in urban areas. However, due to government special interest, it is increasing day by day.

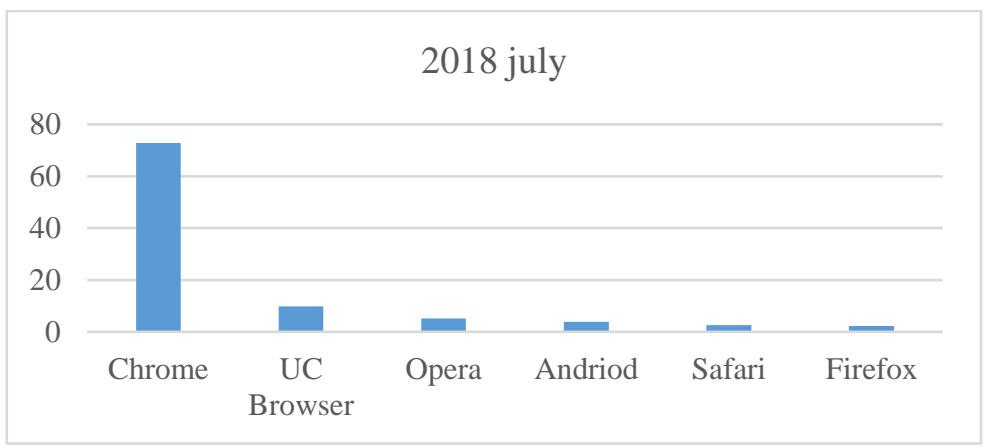

Source: PTA (2018)

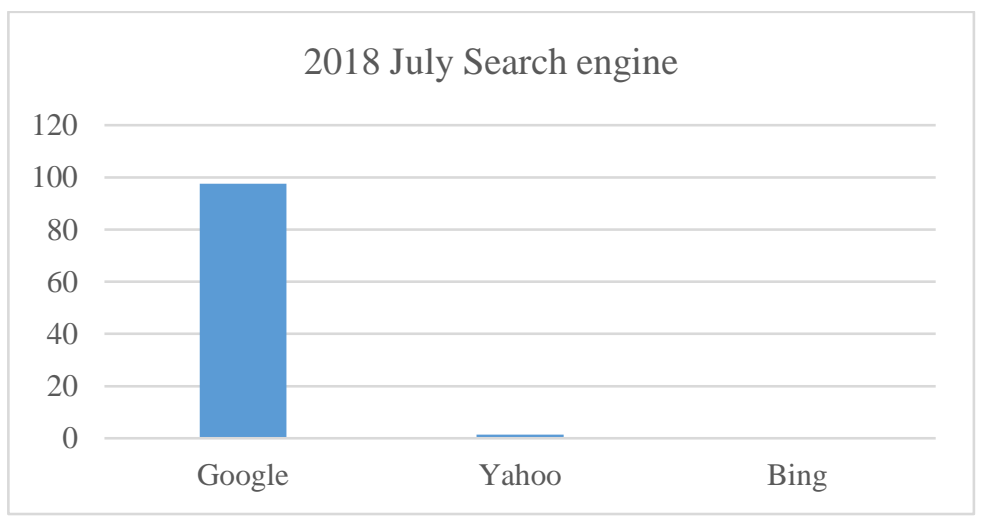

Source: PTA (2018) 
Pakistan Telecommunication Authority released an annual report for the year 2018. This report highlighted that there around 18 million mobile users in the country. However, Pakistan ranked as the $10^{\text {th }}$ country with the least internet freedom in the world. While there is also frequent shutdown of the internet by the government authorities on various sensitive political and religious occasions. While Pakistan has the highest digital divides between genders in the world, however, July 2018 statistics of popular browser by market shares shows; Chrome (72.81\%) leads, followed by Browser UC (9.78\%), Opera (5.17\%), Android (3.91\%), Safari $(2.57 \%)$, and Firefox $(2.27 \%)$. While in regard to most popular search engines, led by Google $(97.59 \%)$, followed by Yahoo $(1.42 \%)$ and Bing $(0.05 \%)$.

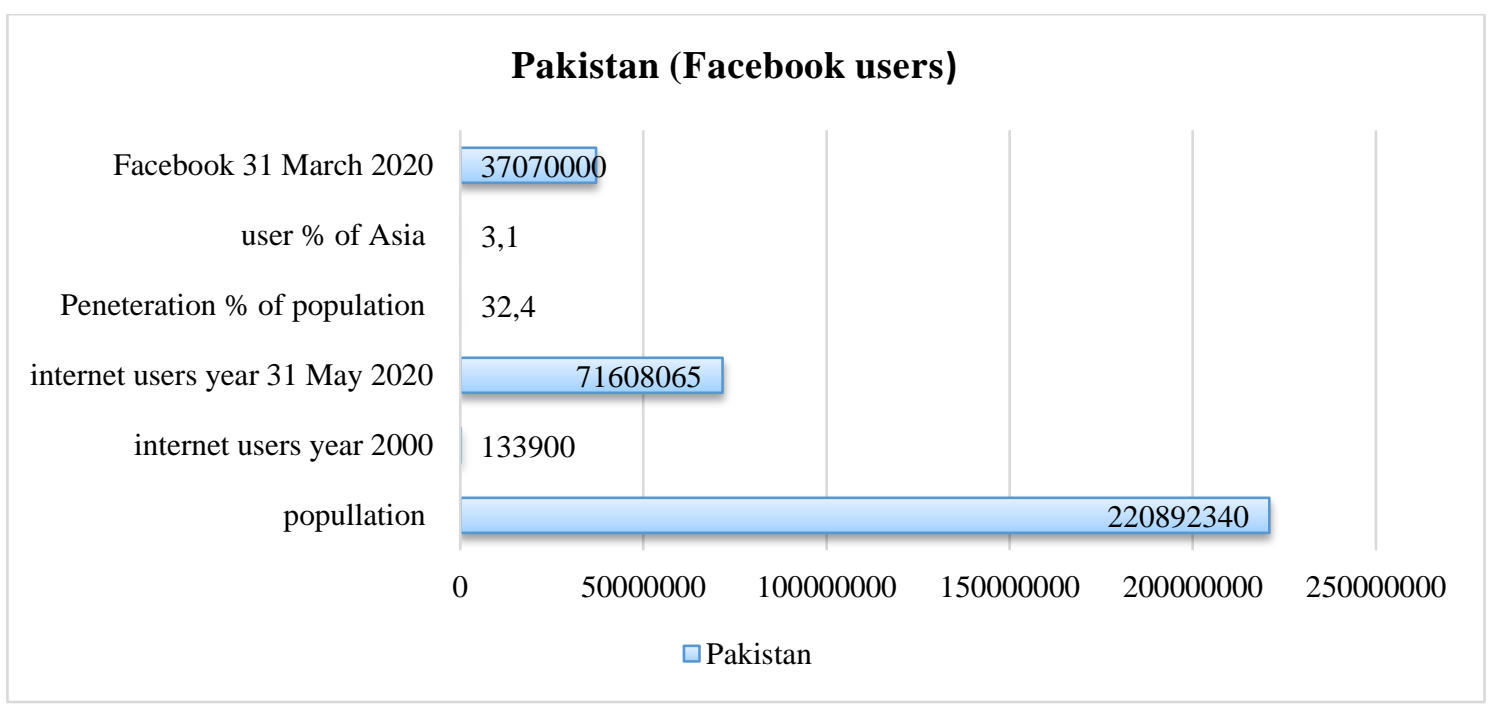

\section{Theoretical Background}

There is fast-growing literature available now, on the economic consequences of the novel COVID-19 pandemic outbreak. As, Binder, Hutter, Pang, and Webb (2020) observed almost 40 percent of people of America concerned about the virus and delayed purchases of tickets, and postponed travel as early as March 2020. Fetzer, Hensel, Hermle, and Roth (2020) argued that the pandemic virus leads to a huge increase in internet searches around the globe. A survey conducted by Hanspal, Weber, and Wohlfart (2020) observed that the COVID-19 has resulted in a loss in the case of both wealth and income. Barrios and Hochberg (2020), and Allcott et al. (2020) discussed the perception of risks associated with non-essential movement and virus spread. Bursztyn, Rao, Roth, and Yanagizawa-Drott (2020) studied the possible effect of COVID-19 in greater consumption of media. While, (Andersen, Rambaut, Lipkin, Holmes, \& Garry, 2020; N. Chen et al., 2020), and Baker et al. (2020) studied the consumption response to the COVID19 pandemic. While quantitatively growing literature combines the pandemic and economic circumstances to quantify the benefits and economic costs of various policies practices implemented (Atkeson, 2020; Barro, Ursua, \& Weng, 2020;
Eichenbaum, Rebelo, \& Trabandt, 2020; Guerrieri, Lorenzoni, Straub, \& Werning, 2020) and (Jones, 2020). This virus has incurred a large number of calamities in the world economy. COVID-19 has been presented as the independent variable in this particular study since the entire economy and the wellbeing of the entire population have relied on this particular pandemic to a greater extent (Hasanat et al., 2020).

In the present scenario higher level of limitations have been imposed on the businesses as well as individuals. According to Fetzer et al. (2020), the COVID-19 is significantly accelerating its transition towards the digitalization of commerce. The economies of the world have been significantly influenced by the pandemic virus; therefore it is identified as an independent variable which is also considered by Hasanat et al. (2020), in their recent e-commerce study. Further, e-commerce is identified as a dependent variable due to the downfall or rise in the online platform demand, dependent significantly on the pandemic virus widespread, and the people's specific behavior as a result of this global issue (Ahmad \& Hui, 2020). Moreover, these two factors influence the overall online business market demand and are considered to be the 
reasons people shifted towards e-commerce approaches (Li \& Li, 2020).

\section{Theory of Planned Behavior}

To understand and predict consumer financial behavior, Ajzen (1991) proposed the theory of planned behavior, an extension to the theory of reasoned action Fishbein and Ajzen (1975) which states that individual behavior and intention are determined by her/his specific behavior. The intention is further determined by individual subjective norms and attitudes (Davis, 1989). According to the theory of planned behavior, which mainly focuses on factors that affecting the actual behavioral choices of the individual (Armitage \& Conner, 2001). This theory categorized behavioral intention influencing factors into mainly three factors: the negative or positive attitude regarding the target behavior, perceived behavior control, and subjective norms. An attitude represents a person's positive or negative evaluation of a relevant behavior, which is a person's salient beliefs regarding the perceived outcomes of behavior. While a person's perception of whether significant referents approve or disapprove of behavior refers to the subjective norm (Ajzen, 1991).

\section{Methodology}

\section{Research Design}

This study employs structural equation modeling (SEM) approach and developed a model that represents the three main variables of the study, i.e. COVID-19 effect, e-business, and consumer behavior to investigate the relationship in the present virus outbreak scenario. We employed the survey method and collected data through self-measured and administered survey questionnaires consisting of demographic and multiple items for each of the three-research variables of the study. Descriptive statistics (such as frequency, percentage, mean) have been performed by using SPSS. The reliability of the questionnaires was assessed and was found satisfactory.

\section{Sampling technique}

Keeping in view the recommended guidelines (Kline, 2005), we collected information from 280 respondents, comprised of 182 Male (65\%), and 98 female (35\%), of online business consumers, who are familiar with and exposed to online purchases of products or services. We targeted the respondents from various, associations, government, academic institutions, and private industries, who occupy the position and have access and complete know-how to online purchasing, with ages ranging from 22 to 60 .

\section{Instrument}

The survey questionnaire is designed with Likert scale ranging from; $1=$ never true to $5=$ very true, to gather data from the respondents. The first section of the questionnaires deals with asking demographic information like; gender, education level, job status, and practice of online purchasing. The second section questionnaire consisted of multiple items, represent all the constructs of the study.

\section{Structural Equation Modelling}

Structural Equation Modeling (SEM) is one of the novel methods for multivariate data analysis, especially to overcome the limitations to traditional Ordinary Least Square (OLS) regressions methodology. Structural equation modeling help in analyzing the inter-relationship between multiple research variables in a developed model (Meyers, Gamst, \& Guarino, 2013; Tabachnick \& Fidell, 1996) and (RainesEudy (2000).

\section{Research Hypothesis of the Study}

H1. The covid-19 outbreak has a significant effect on consumer buying behavior for online products or services.

H2. The Covid-19 has a significant effect on Ebusiness practices on online business in Pakistan. H3. Consumer buying behavior significantly affects E-business practices in Pakistan.

H4. Consumer behavior mediates the relationship between COVID-19 and E-business.

\section{Empirical Techniques}

\section{Descriptive Statistics}

182 Male (65\%), and 98 females (35\%), totaled of 280 respondents from various demographic backgrounds participated in the survey. Descriptive statistics were performed to carefully analyze the obtained data to investigate the respondents spending behavior. The statistics show (see graph 1) the majority of the survey respondents $(51.8 \%)$ purchased Food delivery items followed by Clothing (32.5\%), Services $(10.4 \%)$, Electronics $(3.2 \%)$, and others $(2.1 \%)$. While $49.6 \%$ of total respondents spend up to Rs 
1000 in the last two months, $42.5 \%$ spend up to Rs 5000, 5.4\% replied with spending up to Rs 10000, and $2.5 \%$ spend Rs 2000 on online purchasing in the last two months (see graph 2). $80 \%$ of respondents replied that after the COVID-19 breakout there is a decrease in their disposable income to spend on e-shopping.
While 20\% replied they barely feel any change in their disposable income to spend on (see graph 3 ). However, the preferred payment option cash on delivery $70.7 \%$, followed by online banking $22.1 \%$, and others (e.g. easy paisa, jazz cash. Etc) $7.1 \%$ (see graph 5).

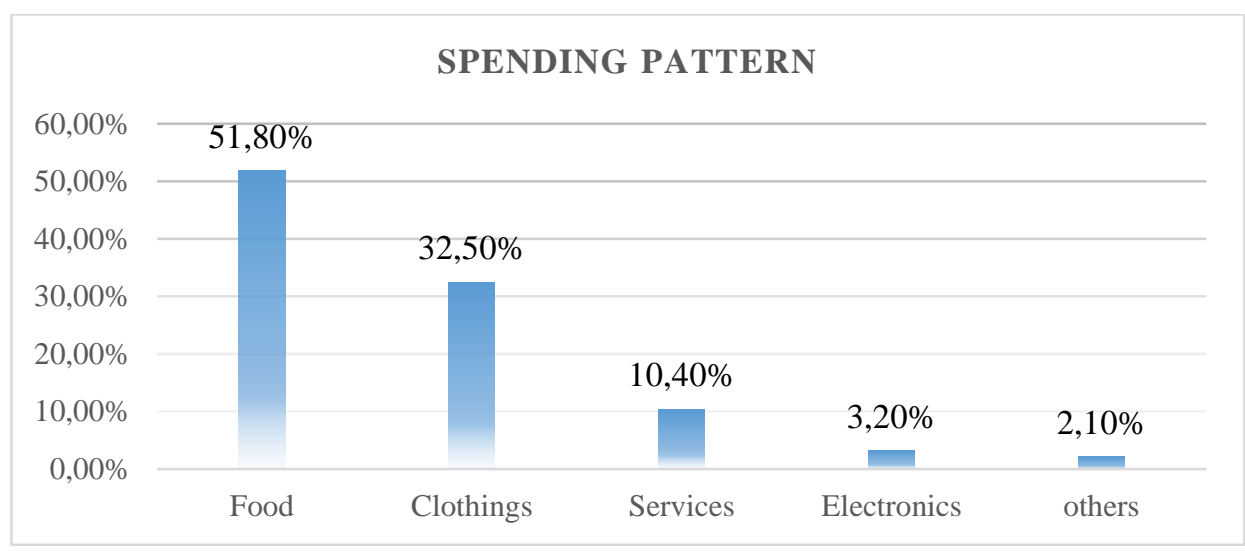

Graph 2. Consumer buying pattern.

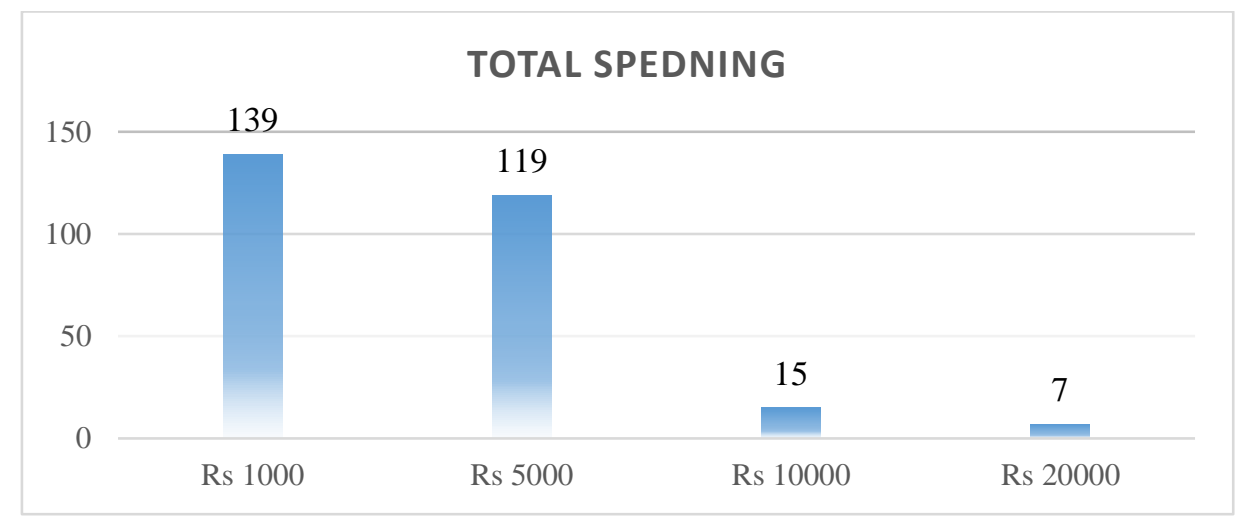

Graph 3. Consumer total spending.

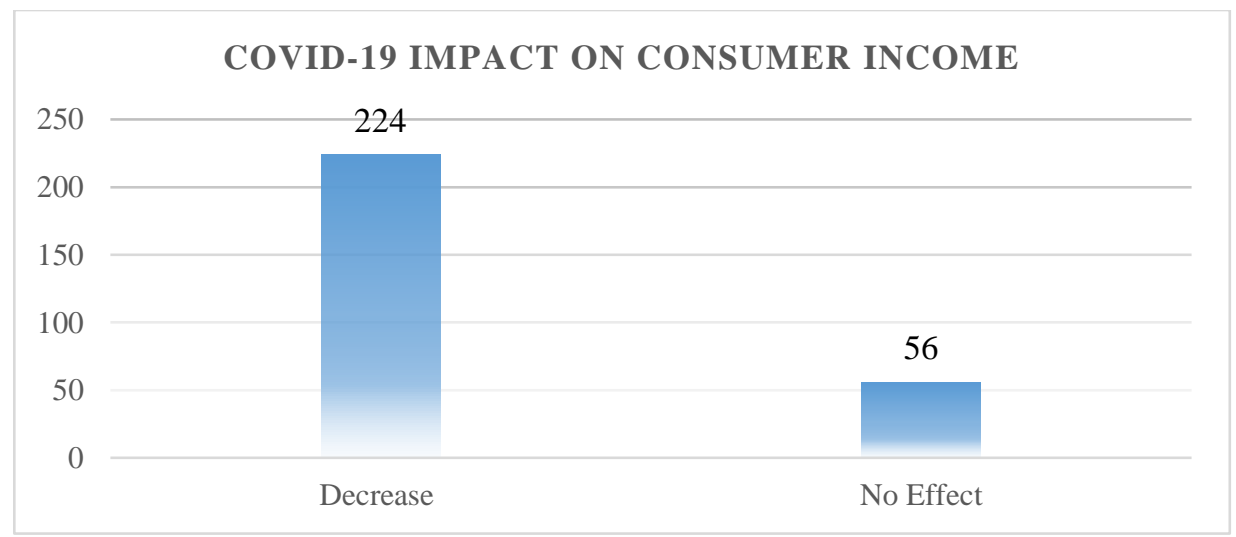

Graph 4. COVID-19 impact on consumer disposable income. 


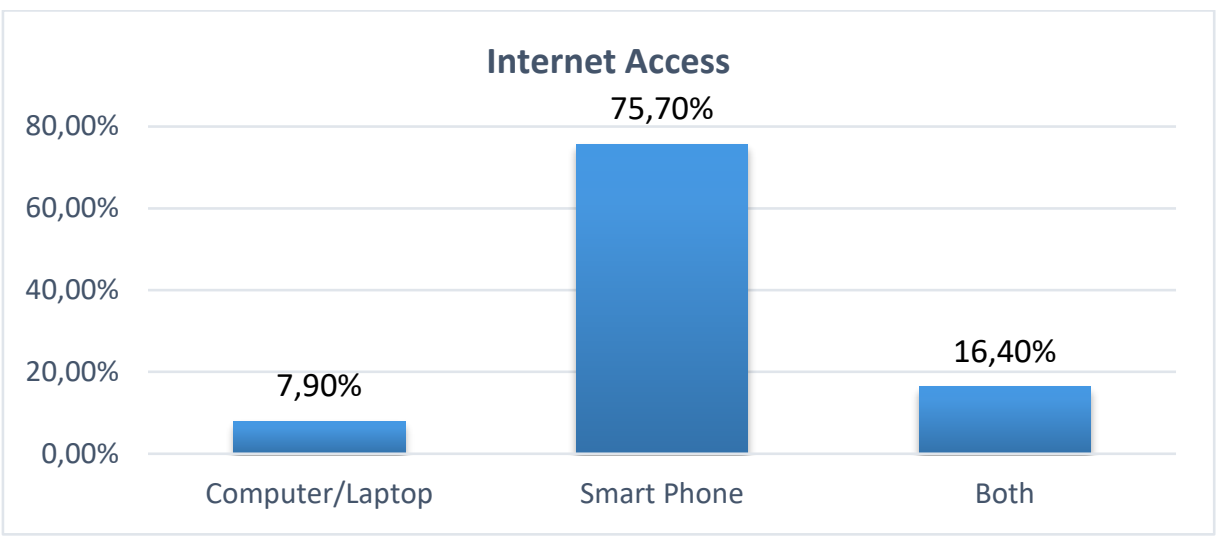

Graph 5. Internet Connectivity.

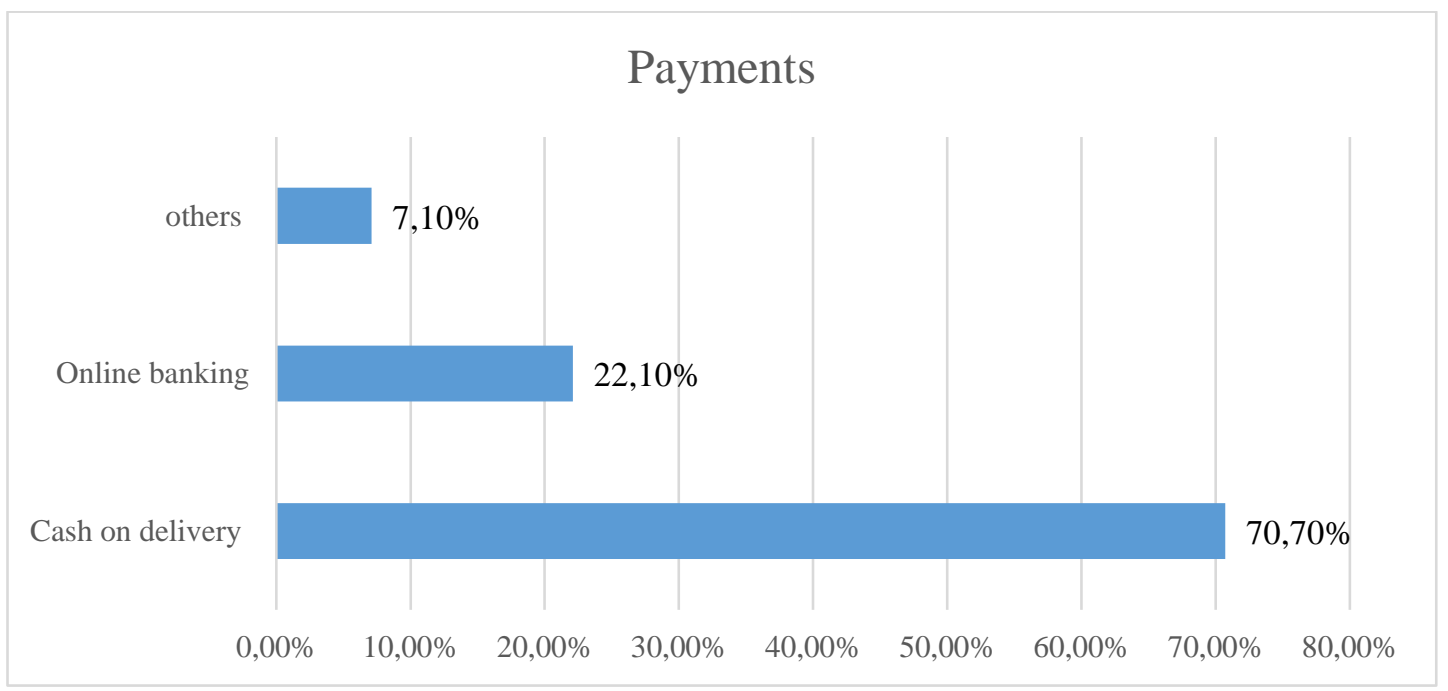

Graph 6. Respondents payment cannel.

Pakistan is home to many e-commerce giants such as homeshopping.pk, and Daraz.pk. However, the barriers shown in graph 6 are the challenges faced by e-commerce platforms customers. This indicates the lack of carrying out extensive research towards consumer greater satisfaction. As per the survey result, $47.5 \%$ of respondents experience low-quality products. However, it has been noticed that many customers just by reading origin made country name ignore the product. This creates a challenge for local dealer reputation. $26.4 \%$ of respondents were curious about the high price e-business companies charge.

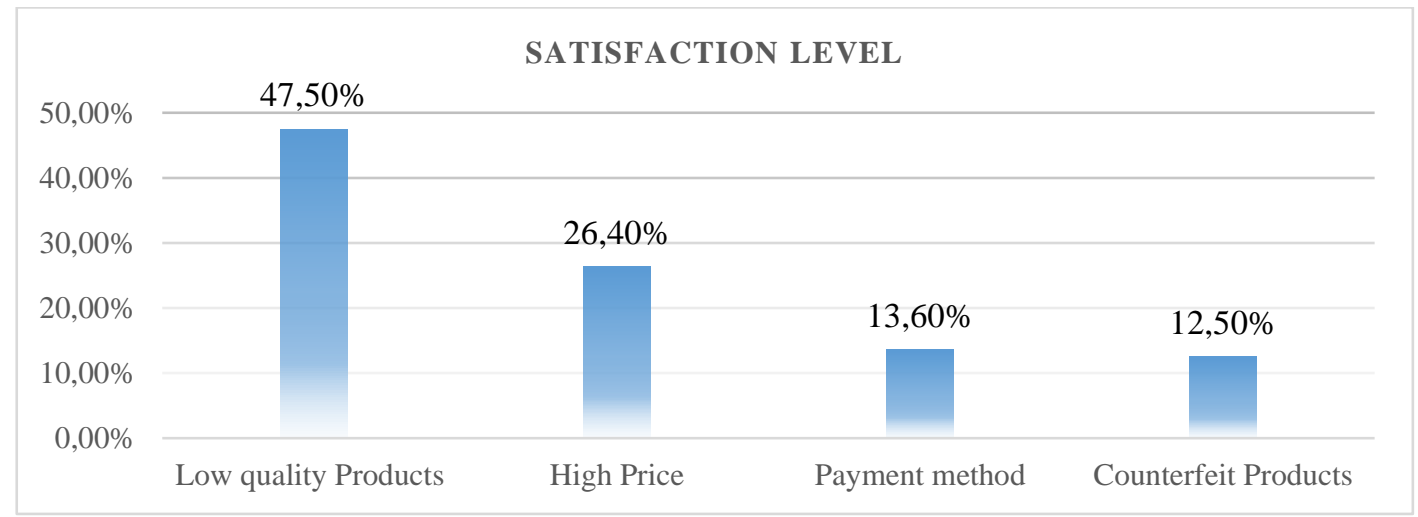

Graph 6. Respondents E-products satisfaction level. 


\section{Reliability and Sample Adequacy Checks}

We performed reliability analysis, using Cronbach alpha test to examine the reliability of the data, collected using various variables of this study. The Cronbach's alpha values are all acceptable ranging as, 0.88 for consumer behavior, 0.89 for e-business, and 0.88 for Covid-19 variable as per reference to Cortina (1993) who suggests that it should not be less than 0.7 . We also analyzed the adequacy and sufficiency of the sample size used in this study, and the reported Kaiser-Meyer-Olkin Measure of Sampling Adequacy (KMO) value is above 0.6, which states that the sample is good enough and further tests can be applied to test the hypothesis. The Barlett's Test of Sphericity (KMO), the value should be significant (i.e. the Sig. value should be .05 or smaller). In this example, the KMO value is .798 and the Bartlett's test is significant $(\mathrm{P}=0.000)$, therefore, factor analysis is appropriate (Bolten, 1989).

\section{Confirmatory Factor Analysis}

CFA is employed to test whether the construct measures are consistent with the understanding of the researcher's nature of the construct. The measurement model of construct before modeling in SEM needs to undergo CFA (RainesEudy, 2000). This study has three exogenous constructs: e-business, consumer behavior, and Covid-19 (perceived risk) as shown in Figure 1. Table 2 represent obtained satisfactory values for convergent validity. Moreover, factor loading values for all the observed items are above the recommended value in literature, i.e. 0.5, as suggested by Bagozzi and Yi (1988), and (Hair, Ringle, \& Sarstedt, 2011).

\section{Measurement Model}

To validate and assessed together this study's three latent constructs, confirmatory factor analysis (CFA) was performed in AMOS grahphic. After performing measurement, certain fitness indexes indexes for the pooled constructs do not achieve the required level (ChiSq/df= 5.245, $\mathrm{RMSEA}=.149, \mathrm{GFI}=.581$, $\mathrm{AGFI}=.547$, and $\mathrm{CFI}=.590)$. therefore, when we examined the factor loading, it was found that factor loading for 2 items, one from the construct ebusiness, and one item from construct consumer behavior is not above 0.5, However, if we look into the rotated component Matrix in SPSS, these items are loaded on two factors.

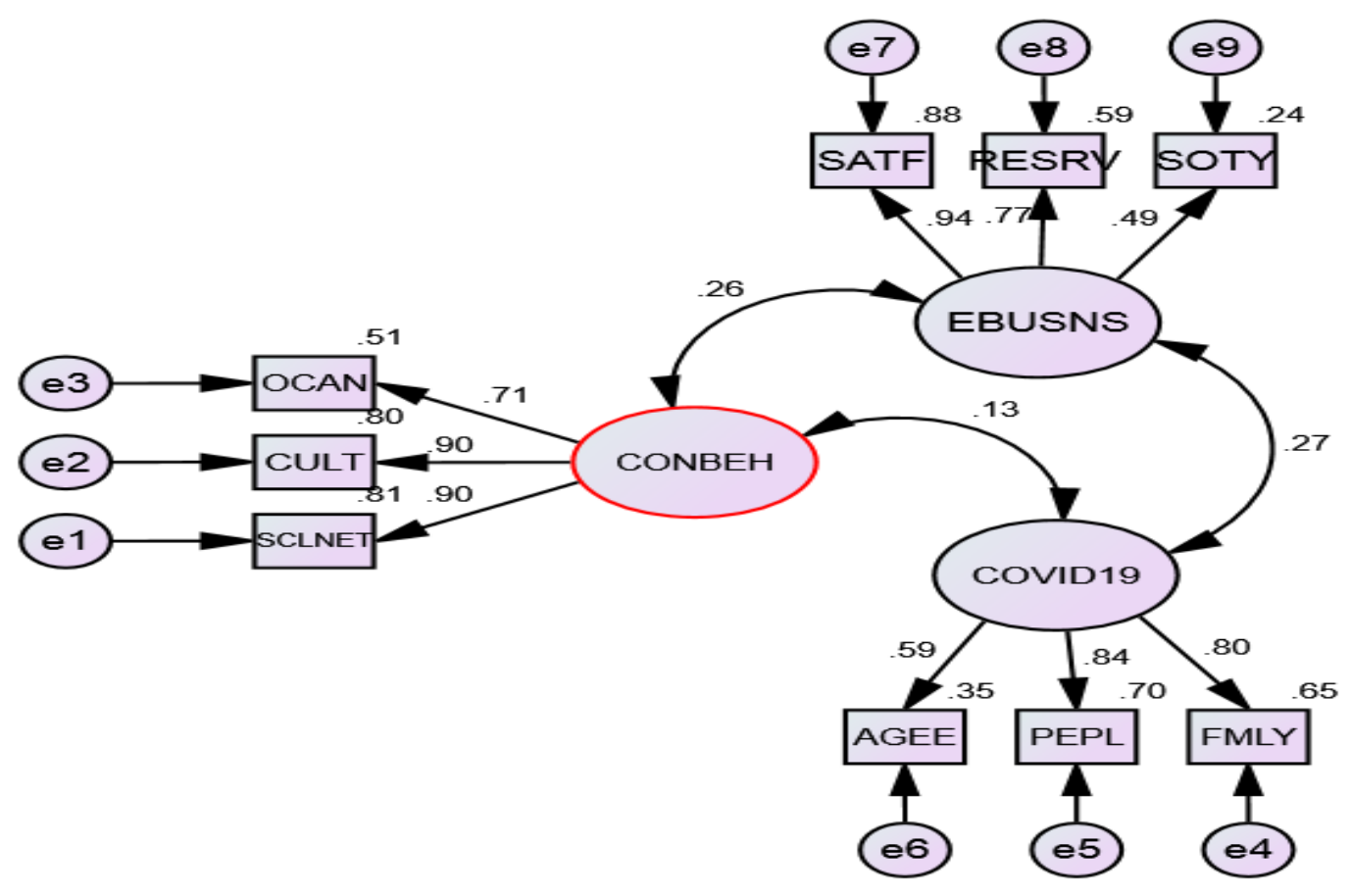

Figure 1. SEM model. 
The fitness index after reducing the items is still below the required level $(\mathrm{ChiSq} / \mathrm{df}=4.107$, RMSEA $=.102$, GFI $=.870$, AGFI $=.808$, and $\mathrm{CFI}=.938$ ), even though the factor loading for all items are above 0.6 . Thus, one might suspect that certain items are redundant to each other in the measurement model. The item redundancy can be examined through inspecting the Modification Indexes (MI), which presents the MI for a pair of correlated errors that reflect redundant items that are existed in the model. The MI value above 15.00 is considered high. The correlated measurement error here between e13 and e15; e13 and e16; e12, e11, and e9 and e10. These items have caused the measurement model to have a poor fit, thus deleted one by one till achieved the required model fitness (Dew \& Xiao, 2011). After modification the required result have been successfully achieved with measurement of $\mathrm{ChiSq} / \mathrm{df}=1.354$, RMSEA $=.036$, GFI $=.975$, AGFI $=.954$, and $\mathrm{CFI}=.992$ ). Table 1 and Table 2 below represent the model fit measurement and Model Validity measures.

Table 1.

Goodness of fit of Structural Equation Modelling.

\begin{tabular}{lllll}
\hline Measure & Estimate & Threshold & Interpretation & Literature \\
\hline CMIN/DF & 1.354 & Between 1 and 3 & Excellent & (Henseler \& Chin, 2010) \\
CFI & 0.992 & $>0.95$ & Excellent & (Peter M Bentler, 1990) \\
GFI & 0.975 & $>0.95$ & Excellent & (Anderson \& Gerbing, 1984) \\
NFI & 0.967 & $>0.95$ & Excellent & (Peter \& Churchill Jr, 1986) \\
RMSEA & 0.036 & $<0.06$ & Excellent & (Henseler \& Chin, 2010) \\
\hline
\end{tabular}

The convergent validity has been obtained as shown in table 4, as all the items in the measurement model are statistically significant. We also verified the convergent validity by computing the AVE (average variance extracted) for each construct and composite reliability. The threshold value commonly used for AVE is 0.5 , and for composite reliability is 0.7 (Hair,
Sarstedt, Pieper, \& Ringle, 2012). The AVE and composite reliability are as per the recommended threshold (see table 2). The Cronbach's alpha coefficients for the construct are e-business 0.88 , for consumer behavior 0.89, and for COVID-19, 0.87 (calculated in SPSS) as shown in table 1, the reliability is achieved as all the values are greater than 0.7 .

Table 2.

Factor loading, AVE, Cronbach alpha, and CR.

\begin{tabular}{llllll}
\hline Construct & Items & Factor loading & AVE & Cronbach $\boldsymbol{\alpha}$ & CR \\
\hline \multirow{5}{*}{ E-Business } & SATF & .94 & & & \\
& RESRV & .77 & .570 & .88 & .78 \\
& SOTY & .49 & & & \\
Consumer & OCAN & .71 & & & .84 \\
behavior & CULT & .90 & .70 & .89 & \\
& SCLNET & .90 & & & .79 \\
COVID-19 & AGEE & .59 & .56 & .87 & \\
\hline
\end{tabular}

Construct validity for the measurement model fitness has been achieved by three indices as shown in Table 2 absolute fit indices, incremental fit indices, and parsimonious fit. Table 3 shows that the obtained value for the CFA measurement model with corresponding acceptance levels is as per the literature. The absolute fit indices with reported values are, as $\mathrm{GFI}=.98, \mathrm{CMIN}) / \mathrm{DF}=1.282$, and RMSEA $=$ .03. The incremental fit indices, with recurring values are, as CFI $=.99, \mathrm{NFI}=.97$, and $\mathrm{TLI}=$ .99. The obtained value shows the overall goodness of fit of the measurement model (see Table 3). This validity is achieved when the measurement model is free from redundant items ( Hair et al., 2011). All the values have a significant correlation between the construct as reported less than 0.85 Peter M Bentler (1990) represent in table 3 . 
Table 3.

Discriminant Validity.

\begin{tabular}{llllllll}
\hline & CR & AVE & MSV & MaxR(H) & CONBEH & COVID19 & EBUSNS \\
\hline CONBEH & 0.876 & 0.705 & 0.068 & 0.902 & $\mathbf{0 . 8 4 0}$ & & \\
COVID19 & 0.794 & 0.567 & 0.075 & 0.826 & $0.134 \dagger$ & $\mathbf{0 . 7 5 3}$ & \\
EBUSNS & 0.789 & 0.570 & 0.075 & 0.901 & $0.260 * * *$ & $0.274 * * *$ & $\mathbf{0 . 7 5 5}$ \\
\hline
\end{tabular}

Table 4.

Standardized Path Coefficients.

\begin{tabular}{lllllll}
\hline & & & Estimate & S.E. & C.R. & P \\
\hline COVID19 & $\rightarrow$ & CONBEH & 0.138 & 0.072 & 1.926 & 0 \\
COVID19 & $\rightarrow$ & EBUSNS & 0.285 & 0.08 & 3.574 & 0 \\
CONBEH & $\rightarrow$ & EBUSNS & 0.258 & 0.073 & 3.535 & 0 \\
\hline
\end{tabular}

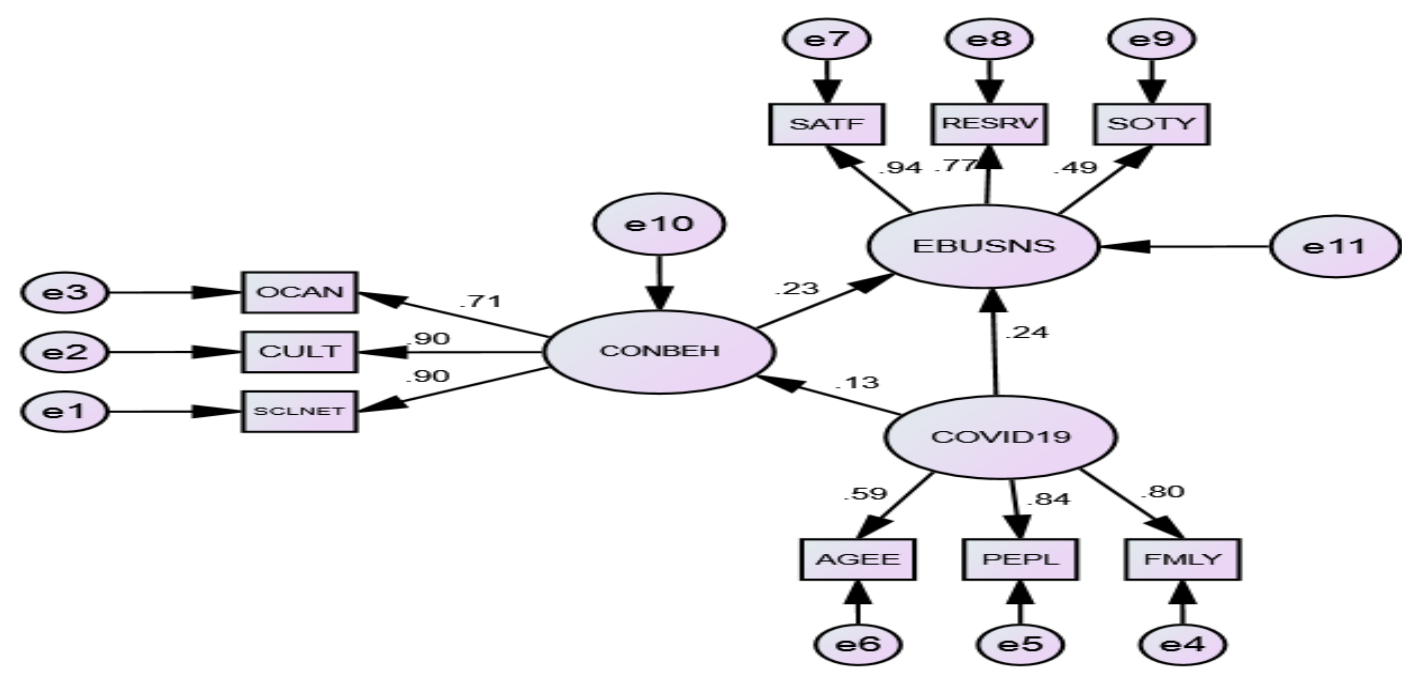

Figure 2.

The model fit has been examined first statistically for the hypothetical model presented in figure 3 , table 4 . Regarding model fit, the chisquare value is $32.497(\mathrm{p}<.001)$, and df (degree of freedom) reported is 24 . The direct effects, factor loading, in-direct effects, and total effects among the constructs have been examined. The standardized regression weight of .285 ( $\mathrm{p}<$
.001 ), in terms of direct effect, is observed from COVID-19 to E-business (see Table 5). While standardized regression weight $.258(\mathrm{p}<.001)$, from consumer behavior to E-business, and standardized regression weight of .138 ( $\mathrm{p}<$ .001 ), from COVID-19 to consumer behavior is observed (see table 5).

Table 5.

Direct, Indirect, and Total Effects.

\begin{tabular}{lllll}
\hline Constructs & & Direct effects & Indirect effects & Total effects \\
\hline Dependent & Independent & & & \\
E-Business & COVID-19 & .243 & .030 & .274 \\
& CONBEH & .228 & .000 & .228 \\
CONBEH & COVID-19 & .134 & .000 & .134 \\
\hline
\end{tabular}


As shown in Table 5 there is one indirect effect in this research model, and the standardized value from COVID-19 to E-business is .030. The mediating factor of each indirect effect path is consumer behavior. The total effect and indirect effect between Consumer behavior and Ebusiness are the same since there is a statistically significant direct effect between E-business and consumer behavior (Table 4). The reported results imply that Consumer behavior affects Ebusiness only indirectly through COVID-19 in this model. The below graph shows the ecommerce activities in the first 3 months of the pandemic.

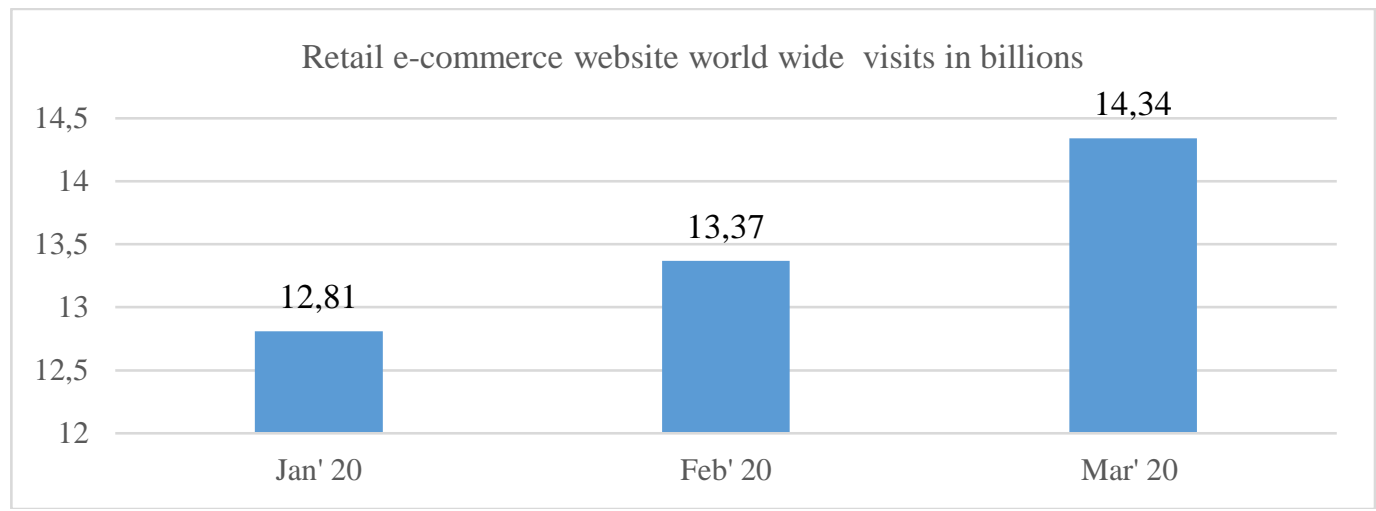

Graph 7. online retail users statistics 2020 (source: Statista.com)

\section{Discussion and Conclusion}

The pandemic coronavirus shuts down country after country and has changed the world immeasurably in recent few months. However, for sure there will be a substantial economic toll for the businesses. Technology is doing its best by helping people to remain in touch virtually in the lockdown. Social media, other online activities usage have skyrocketed. Retail online platforms have six percent globally increased from January to March 2020. As per statista.com, 14.34 billion people visited in March. The increase has been seen, because of the global COVID-19 pandemic, which caused the lockdown of millions of people to stay at home around the globe to stop spreading the virus. Consumers have no choice left with them except to turn to the internet to get their daily items like groceries and others (www.statista.com).

Today, customers search multiple search engines, i.e. websites, and even markets before actual purchase. One of the possible reasons which may add is that different e-commerce platforms stock products of the same nature with different price options, thus creating a quest for comparison, but many fail to come up with a better price. $13.6 \%$ of the respondents are not happy with the payment options. One of the possible reasons behind this is the security of online transactions and payments. While the ground fact is also there that majority of the Pakistani people don't even have a bank account. However, on the other side, recent statistics show that only $3 \%$ of internet users in Pakistan have purchased using internet channels as compared to the USA, where $72 \%$ of users are digital shoppers. $12.5 \%$ of respondents are afraid of counterfeit products, which indicates the least statically, but alarming issue consumer-facing. E-commerce platforms should come up with solid rules policy to prevent their customer from being the victims. For instance, Alibaba initiated a way to curb fake product sales. The covid-19 outbreak has impacted online payment and ecommerce worldwide. Research and Markets report shows that online shopper penetration increases during the pandemic. However, the overall volumes of payments are expected to decrease in 2020, due to major losses in-store and travel segments.

The data analysis of this study illustrating the established positive impact of COVID-19 on electronic business in Pakistan. The established positive COVID-19 is impacting both other variables, i.e. the consumer buying behavior and the e-business to a greater extent. However, COVID-19 is threatening the business environment in Pakistan. Retailers are experiencing the most difficult situation and challenges which lowering customer buying behavior. This consequently results in lowering the inventory due to lack of shipping and supply. Results indicate that online businesses face several issues during the lockdown, which impacts sales and production. Due to irregular supply of intermediate goods, and raw materials, and supply chain distortion, resulting in loss of revenue and shortage of liquidity for business operations. 


\section{References}

Abebe, M. (2014). Electronic commerce adoption, entrepreneurial orientation and smalland medium-sized enterprise (SME) performance. Journal of small business and enterprise development, Vol 1(1)

Ahmad, T., \& Hui, J. (2020). One Health approach and Coronavirus Disease 2019. Human Vaccines \& Immunotherapeutics, 16(4), 931.

Ahmed, Y. A., Ahmad, M. N., Ahmad, N., \& Zakaria, N. H. (2019). Social media for knowledge-sharing: A systematic literature review. Telematics and informatics, 37, 72-112. Ajzen, I. (1991). The theory of planned behavior. Organizational behavior and human decision processes, 50(2), 179-211.

Allcott, H., Boxell, L., Conway, J., Gentzkow, M., Thaler, M., \& Yang, D. Y. (2020). Polarization and public health: Partisan differences in social distancing during the Coronavirus pandemic. NBER Working Paper (w26946).

Andersen, K. G., Rambaut, A., Lipkin, W. I., Holmes, E. C., \& Garry, R. F. (2020). The proximal origin of SARS-CoV-2. Nature medicine, 26(4), 450-452.

Anderson, J. C., \& Gerbing, D. W. (1984). The effect of sampling error on convergence, improper solutions, and goodness-of-fit indices for maximum likelihood confirmatory factor analysis. Psychometrika, 49(2), 155-173.

Apăvăloaie, E.-I. (2014). The impact of the internet on the business environment. Procedia Economics and finance, 15, 951-958.

Armitage, C. J., \& Conner, M. (2001). Efficacy of the theory of planned behaviour: A metaanalytic review. British journal of social psychology, 40(4), 471-499.

Atkeson, A. (2020). What will be the economic impact of COVID-19 in the US? Rough estimates of disease scenarios). National Bureau of Economic Research

Bagozzi, R. P., \& Yi, Y. (1988). On the evaluation of structural equation models. Journal of the academy of marketing science 16(1), 74-94.

Baker, S. R., Bloom, N., Davis, S. J., Kost, K. J., Sammon, M. C., \& Viratyosin, T. (2020). The unprecedented stock market impact of COVID19 (0898-2937). Working Paper 26945, National Bureau of Economic Research.

Baldwin, R., \& Mauro, B. W. d. (2020). Economics in the Time of COVID-19. CEPR Press.

Barrios, J. M., \& Hochberg, Y. (2020). Risk perception through the lens of politics in the time of the covid-19 pandemic (0898-2937). University of Chicago, Becker Friedman
Institute for Economics Working Paper, (2020-32). 1, 5.3

Barro, R., Ursua, J., \& Weng, J. (2020). Coronavirus Meets the Great Influenza Pandemic. VoxEU. org, 20.

Barrot, J.-N., Grassi, B., \& Sauvagnat, J. (2020). Sectoral effects of social distancing. Covid Economics 3.

Bartik, A. W., Bertrand, M., Cullen, Z. B., Glaeser, E. L., Luca, M., \& Stanton, C. T. (2020). How are small businesses adjusting to covid-19? early evidence from a survey (0898-2937). NBER Working Paper No. 26989. National Bureau of Economic Research.

Bentler, P. M. (1990). Comparative fit indexes in structural models. Psychological bulletin, 107(2), 238

Binder, C. R., Hutter, M., Pang, M., \& Webb, R. (2020). System science and sustainability assessment. Sustainability Assessment of Urban Systems, 30.

Bolten, J. J. (1989). The right to seek asylum in Europe. Neth. Q. Hum. Rts., 7, 381.

Boore, C., James, N. M., \& Iraki, X. (2017). Strategic issues in e-Health implementation in developing countries: The Kenyan healthcare sector. Global Scientific Journals, 5(7), 50-62.

Borges, M., Hoppen, N., \& Luce, F. B. (2009). Information technology impact on market orientation in e-business. Journal of business research, 62(9), 883-890.

Bounie, D., Camara, Y., \& Galbraith, J. W. (2020). Consumers' Mobility, Expenditure and Online-Offline Substitution Response to COVID-19: Evidence from French Transaction Data. Available at SSRN 3588373.

Bullard, A. (2020). Derecho y Economía: El análisis económico de las instituciones legales: Palestra Editores.

Bursztyn, L., Rao, A., Roth, C., \& YanagizawaDrott, D. (2020). Misinformation during a pandemic. University of Chicago, Becker Friedman Institute for Economics Working Paper (2020-44).

Cajner, T., Crane, L. D., Decker, R. A., Grigsby, J., Hamins-Puertolas, A., Hurst, E., Yildirmaz, A. (2020). The US labor market during the beginning of the pandemic recession (08982937), Working Paper 27159

Chen, N., Zhou, M., Dong, X., Qu, J., Gong, F., Han, Y., Wei, Y. (2020). Epidemiological and clinical characteristics of 99 cases of 2019 novel coronavirus pneumonia in Wuhan, China: a descriptive study. The Lancet, 395(10223), 507-513.

Chen, W., Jin, W., Hardegen, N., Lei, K.-j., Li, L., Marinos, N., Wahl, S. M. (2003). Conversion of peripheral CD4+ CD25- naive T cells to CD4+ CD25+ regulatory $\mathrm{T}$ cells by TGF- 
$\beta$ induction of transcription factor Foxp3. The Journal of experimental medicine, 198(12), 1875-1886.

Cohen, P. A. (2020). Between Tradition and Modernity: Wang T'ao and Reform in Late Ching China. Brill, Cumberland (Harvard University Press)

Cook, A. D., \& Yogendran, S. (2020). Conceptualising humanitarian civil-military partnerships in the Asia-Pacific:(Re-) ordering cooperation. Australian Journal of International Affairs, 74(1), 35-53.

Cortina, J. M. (1993). Interaction, nonlinearity, and multicollinearity: Implications for multiple regression. Journal of Management 19(4), 915-922.

Craven, M., Liu, L., Mysore, M., \& Wilson, M. (2020). COVID-19: Implications for business. McKinsey \& Company.

Davis, F. D. (1989). Perceived usefulness, perceived ease of use, and user acceptance of information technology. MIS quarterly, 319-340. Dew, J., \& Xiao, J. J. (2011). The financial management behavior scale: Development and validation. Journal of Financial Counseling and Planning, 22(1), 43.

Dinev, T., \& Hart, P. (2006). An extended privacy calculus model for e-commerce transactions. Information systems research, 17(1), 61-80.

Dunford, M., Gao, B., \& Li, W. (2020). Who, where and why? Characterizing China's rural population and residual rural poverty. Area Development and Policy, 5(1), 89-118.

Fang, Y.-H. (2014). Beyond the credibility of electronic word of mouth: Exploring eWOM adoption on social networking sites from affective and curiosity perspectives. International Journal of Electronic Commerce, 18(3), 67-102.

Feizollahi, S., Shirmohammadi, A., Kahreh, Z. S., \& Kaherh, M. S. (2014). Investigation the effect of internet technology on performance of services organizations with e-commerce orientations. Procedia-social and behavioral sciences, 109(1), 605-609.

Fetzer, T., Hensel, L., Hermle, J., \& Roth, C. (2020). Coronavirus perceptions and economic anxiety. Review of Economics and Statistics, 1-36.

Fishbein, M., \& Ajzen, I. (1975). Intention and Behavior: An introduction to theory and research. Addison-Wesley, Reading, MA.

Gössling, S., Scott, D., \& Hall, C. M. (2020). Pandemics, tourism and global change: a rapid assessment of COVID-19. Journal of Sustainable Tourism, 1-20.
Grabner-Kräuter, S., \& Kaluscha, E. A. (2003). Empirical research in on-line trust: a review and critical assessment. International journal of human-computer studies, 58(6), 783-812.

Gretzel, U., Fuchs, M., Baggio, R., Hoepken, W., Law, R., Neidhardt, J., Xiang, Z. (2020). ETourism beyond COVID-19: a call for transformative research. Information Technology \& Tourism, 1.

Hair, J. F., Ringle, C. M., \& Sarstedt, M. (2011). PLS-SEM: Indeed a silver bullet. Journal of Marketing theory Practice 19(2), 139-152.

Hajli, M. N. (2014). A study of the impact of social media on consumers. International Journal of Market Research, 56(3), 387-404.

Hall, C. M., Scott, D., \& Gössling, S. (2020). Pandemics, transformations and tourism: be careful what you wish for. Tourism Geographies, $1-22$.

Hanspal, T., Weber, A., \& Wohlfart, J. (2020). Income and wealth shocks and expectations during the COVID-19 pandemic. CEBI Working Paper Series .

Hasanat, M. W., Hoque, A., Shikha, F. A., Anwar, M., Hamid, A. B. A., \& Tat, H. H. (2020). The Impact of Coronavirus (Covid-19) on E-Business in Malaysia. Asian Journal of Multidisciplinary Studies, 3(1), 85-90.

Henseler, J., \& Chin, W. W. (2010). A comparison of approaches for the analysis of interaction effects between latent variables using partial least squares path modeling. Structural equation modeling, 17(1), 82-109.

Hollenbeck, C. R., \& Kaikati, A. M. (2012). Consumers' use of brands to reflect their actual and ideal selves on Facebook. International Journal of Research in Marketing, 29(4), 395-405.

Inoue, H., \& Todo, Y. (2020). The propagation of the economic impact through supply chains: The case of a mega-city lockdown against the spread of COVID-19. Available at SSRN 3564898.

Jahng, N., Krug, D., \& Zhang, Z. (2007). Student achievement in online distance education compared to face-to-face education. European Journal of Open, Distance and E-Learning, 10(1). Jai, T.-M. C., Burns, L. D., \& King, N. J. (2013). The effect of behavioral tracking practices on consumers' shopping evaluations and repurchase intention toward trusted online retailers. Computers in Human Behavior, 29(3), 901-909. Jones, P. (2020). The arts therapies: A revolution in healthcare. Routledge.

Kowalewski, O., \& Śpiewanowski, P. (2020). Stock market response to potash mine disasters. Journal of Commodity Markets, 100124. 
Kulshrestha, J., Eslami, M., Messias, J., Zafar, M. B., Ghosh, S., Gummadi, K. P., \& Karahalios, K. (2017). Quantifying search bias: investigating sources of bias for political searches in social media," in Proceedings of the 2017 ACM Conference on Computer Supported Cooperative Work and Social Computing, CSCW '17 (New York, NY: ACM), 417-432.

Lai, C.-C., Shih, T.-P., Ko, W.-C., Tang, H.-J., \& Hsueh, P.-R. (2020). Severe acute respiratory syndrome coronavirus 2 (SARS-CoV-2) and corona virus disease-2019 (COVID-19): the epidemic and the challenges. International journal of antimicrobial agents, 105924.

Li, K. J., \& Li, X. (2020). COVID-19 Pandemic: Social Distancing, Public Policy, and Market Response. Public Policy, and Market Response. Available at SSRN.

McKibbin, W., \& Fernando, R. (2020). The economic impact of COVID-19. Economics in the Time of COVID-19, 45.

McKinsey, D. S., \& Pappas, P. G. (2020). Histoplasmosis: time to redraw the map and up our game. Oxford University Press US.

Meyers, L. S., Gamst, G. C., \& Guarino, A. (2013). Performing data analysis using IBM SPSS. John Wiley \& Sons.

Muellbauer, J. (2020). The coronavirus pandemic and US consumption. INET Oxford COVID-19 Blog. 23 March 2020.

Myers, D. (2020). Surfactant science and technology. John Wiley \& Sons.

Peter, J. P., \& Churchill Jr, G. A. (1986). Relationships among research design choices and psychometric properties of rating scales: A metaanalysis. Journal of Marketing Research, 23(1), 1-10.

Rahayu, R., \& Day, J. (2015). Determinant factors of e-commerce adoption by SMEs in developing country: evidence from Indonesia. Procedia-social and behavioral sciences, 195, 142-150.

Raines-Eudy, R. (2000). Using structural equation modeling to test for differential reliability and validity: An empirical demonstration. Structural Equation Modeling 7(1), 124-141.

Sebora, T. C., Lee, S. M., \& Sukasame, N. (2009). Critical success factors for e-commerce entrepreneurship: an empirical study of Thailand. Small Business Economics, 32(3), 303-316.

Shahzad, A., Chin, H. K., Altaf, M., \& Bajwa, F. A. (2020). Malaysian SME's performance and the use of e-commerce: A multi-group analysis of click-and-mortar and pure-play e-retailers. Pakistan Journal of Commerce and Social Sciences (PJCSS), 14(1), 1-33.

Sharot, T., \& Sunstein, C. R. (2020). How people decide what they want to know. Nature Human Behaviour, 1-6.

Tabachnick, B. G., \& Fidell, L. S. J. C. H. C. (1996). Using multivariate statistics Vol. 5 Pearson Boston, MA.

Tarhini, A., Alalwan, A. A., Shammout, A. B., \& Al-Badi, A. (2019). An analysis of the factors affecting mobile commerce adoption in developing countries. Review of International Business and Strategy. Vol 29(3)

UNCTAD. (2020). The Covid-19 Shock to Developing Countries: Towards a 'Whatever It Takes' Programme for the Two-thirds of the World's Population Being Left Behind. Geneva. https://reliefweb.int/sites/reliefweb.int/files/reso urces/gds_tdr2019_covid2_en.pdf

Venkatesh, V., Morris, M. G., Davis, G. B., \& Davis, F. D. (2003). User acceptance of information technology: Toward a unified view. MIS quarterly, 425-478.

Wagner, E. W. (2020). The Literati Purges: Political Conflict in Early Yi Korea. Brill.

Zhong, Z., Zheng, L., Kang, G., Li, S., \& Yang, Y. (2020). Random Erasing Data Augmentation. Proceedings of the AAAI Conference on Artificial Intelligence, 34(07), 13001-13008 